\title{
Assessing the reaction conditions to mediate the milkfat-soybean oil enzymatic interesterification
}

\author{
Determinação das condições reacionais para mediar a interesterificação \\ enzimática da gordura do leite e do óleo de soja
}

\author{
Ariela Veloso de Paula1*, Gisele Fátima Morais Nunes², Heizir Ferreira de Castro ${ }^{3}$, Júlio César dos Santos ${ }^{3}$ \\ IUniv Estadual Paulista (UNESP), Faculdade de Ciências Farmacêuticas, Departamento de Bioprocessos e Biotecnologia, Araraquara/SP - Brazil \\ ${ }^{2}$ Centro Federal de Educação Tecnológica de Minas Gerais (CEFET/MG), Belo Horizonte/MG - Brazil \\ ${ }^{3}$ Universidade de São Paulo (USP), Engineering School of Lorena, Lorena/SP - Brazil
}

\begin{abstract}
*Corresponding Author
Ariela Veloso de Paula, Univ Estadual Paulista (UNESP), Faculdade de Ciências Farmacêuticas, Departamento de Bioprocessos e Biotecnologia, Rodovia Araraquara-Jaú, km 1, CEP: 14801-902, Araraquara/SP - Brazil, e-mail: ariela@fcfar.unesp.br
\end{abstract}

Cite as: Assessing the reaction conditions to mediate the milkfat-soybean oil enzymatic interesterification. Braz. J. Food Technol., v. 19, e2015116, 2016.

Received: Dec. 30, 2015; Accepted: Aug. 25, 2016

\section{Summary}

A food grade lipase from Rhizopus oryzae immobilized on a hybrid polysiloxane-polyvinyl alcohol matrix ( $\mathrm{SiO}_{2}-\mathrm{PVA}$ ) was used as the biocatalyst to mediate the interesterification reactions of a blend containing $65 \%$ milkfat and $35 \%$ soybean oil. All the reactions occurred in an inert nitrogen atmosphere in cylindrical glass reactors ( $80 \mathrm{~mL}$ ) with $40 \mathrm{~g}$ of the milkfat-soybean oil blend. The influence of the following variables was evaluated: biocatalyst loading (250-1500 activity units per gram of blend), biocatalyst moisture content $(5-20 \%)$, temperature $\left(45-60{ }^{\circ} \mathrm{C}\right)$ and incubation time $(2-48 \mathrm{~h})$. The reactions were monitored by determining the free fatty acid content, triacylglycerol (TAGs) composition in carbon species, and the consistency of the interesterified (IE) products. The reaction conditions were set based on the parameters that provided a high interesterification yield and good consistency of the final product within the ideal range (200 to $800 \mathrm{gf} \mathrm{cm}^{-2}$ ). Hence the best results were obtained using a biocatalyst loading of $500 \mathrm{U} \mathrm{g}^{-1}$ of blend with $10 \%$ moisture content at $45^{\circ} \mathrm{C}$ for $4 \mathrm{~h}$. Under these conditions the consistency of the interesterified product was $539.7 \pm 38 \mathrm{~g} \mathrm{~cm}^{-2}$. The results demonstrated the potential of the immobilized lipase to alter the TAGs profile of the milkfat-soybean oil blend, allowing for the production of structured lipids.

Keywords: Rhizopus oryzae lipase; Milkfat; Soybean oil; Interesterification.

\section{Resumo}

Lipase de grau alimentício de Rhizopus oryzae, imobilizada em uma matriz híbrida de polissiloxano-polivinilálcool $\left(\mathrm{SiO}_{2}-\mathrm{PVA}\right)$, foi usada como biocatalisador para mediar reações de interesterificação de uma mistura contendo $65 \%$ de gordura de leite e 35\% de óleo de soja. Todas as reações ocorreram sob atmosfera inerte de nitrogênio, em reatores de vidro cilíndricos ( $80 \mathrm{~mL}$ ) com $40 \mathrm{~g}$ da mistura. Avaliou-se a influência das seguintes variáveis: carregamento de biocatalisador (250-1.500 unidades de atividade por grama de mistura), umidade do biocatalisador (5-20\%), temperatura $\left(45-60{ }^{\circ} \mathrm{C}\right.$ ) e tempo de incubação (2-48 h). O progresso das reações foi monitorado pela determinação do conteúdo de ácidos graxos livres, da composição em triacilgliceróis (TAGs) em espécies de carbono e da consistência de produtos interesterificados (IE). As condições reacionais foram estabelecidas com base nos parâmetros que proporcionaram alto grau de interesterificação e consistência do produto final dentro da faixa ideal (200 a $800 \mathrm{gf} \mathrm{cm}^{-2}$ ). Neste contexto, os melhores resultados foram obtidos utilizando-se $500 \mathrm{U}$ de biocatalisador por grama de mistura, com $10 \%$ de umidade, a $45{ }^{\circ} \mathrm{C}$, durante 4 h. Sob essas condições, o valor de consistência do produto interesterificado foi 539,7 $\pm 38 \mathrm{gf} \mathrm{cm}^{-2}$. Os resultados demonstraram o potencial da lipase imobilizada para alterar o perfil de TAGs da mistura gordura de leite e óleo de soja, permitindo a síntese de lipídios estruturados.

Palavras-chave: Lipase de Rhizopus oryzae; Gordura de leite; Óleo de soja; Interesterificação. 


\section{Introduction}

Interesterification consists of the interchange of acyl groups between two ester molecules to produce new and more valuable esters with specific properties, such as tailor-made fats. Oil and fat modification by interesterification can be carried out via a chemical route using metallic sodium or sodium methylate as the catalyst. In this case, the fatty acid (FA) redistribution occurs at random, and the high temperature and pressure conditions affect the final sensory properties of the product, resulting in the need for additional purification (NUNES et al., 2010). Enzymatic interesterification using lipases (EC 3.1.1.3; triacylglycerol acylhydrolases) is advantageous because the milder conditions allow for a process design with fewer unit operations and lower investment requirements (SOUMANOU et al., 2013). Moreover, another advantage is its minimum generation of byproducts, since lipases are highly regioselective in their reactions (MUKHERJEE, 2014).

Lipases are one of the enzyme classes most widely employed in industry, in part because of their potential to work in non-aqueous environments, and they are applied on an industrial scale for the transesterification of fats and oils in the food segment (FERRARIO et al., 2013). To ensure optimal biocatalyst activity and attain high yield reactions, several factors must be taken into consideration, mainly the temperature, water content and the loading of the biocatalyst in the reaction medium (MARTINS et al., 2013; FRIEDRICH et al., 2012).

In a previous work, a food grade lipase from Rhizopus oryzae immobilized on a hybrid polysiloxane-polyvinyl alcohol matrix was chosen as the biocatalyst to mediate the interesterification reactions of a blend containing $65 \%$ milkfat and 35\% soybean oil (PAULA et al., 2010a). In the present work, attention was given to the assessment of other parameters that can affect the reaction performance, such as the enzyme loading, biocatalyst moisture content and the temperature, verifying their influence on the free fatty acid content, triacylglycerol (TAG) composition and consistency. The consistency was evaluated considering that an enzymatic reaction modifies the texture of the blends in relation to the values of the physical mixture of the raw materials, making them more spreadable under cool temperature conditions.

\section{Material and methods}

\subsection{Materials}

A commercial food grade lipase from Rhizopus oryzae (L036P, Biocatalysts, Cardiff, England) in powder form was used without further purification. Milkfat was obtained from commercial unsalted butter (Aviação, purchased at a local market) and totally melted at 50 to $65^{\circ} \mathrm{C}$ in a microwave oven, followed by centrifugation at $2136 \times \mathrm{g}$ for $10 \mathrm{~min}$ to separate the aqueous phase. Refined, bleached, and deodorized soybean oil was purchased at a local market.

Commercial virgin olive oil ( $0.3 \%$ acidity), purchased at a local market, was used to determine the biocatalyst activity. Tetraethoxysilane (TEOS) and polyvinyl alcohol (PVA, MW 88,000) were acquired from Aldrich Chemical Co. (Milwaukee, WI, USA). Hydrochloric acid (minimum $36 \%$ ), ethanol (minimum 99\%) and polyethylene glycol (PEG $1500 \mathrm{~g} / \mathrm{mol}$ ) were supplied by Synth (São Paulo, Brazil). All solvents and reagents for analyses were of chromatographic or analytical grade.

\subsection{Support preparation and lipase immobilization}

The hybrid matrix of $\mathrm{SiO}_{2}$-PVA was prepared by a sol-gel technique and activated with sodium metaperiodate, as described elsewhere (PAULA et al., 2010b). The activated hybrid particles were soaked in hexane with stirring (100 rpm) for $1 \mathrm{~h}$ at $25^{\circ} \mathrm{C}$. The excess hexane was then removed and the lipase added in a ratio of 1:4 $\mathrm{g}$ of enzyme per gram of support. The PEG-1500 was added together with the enzyme at a fixed loading (5 $\mathrm{mg} \mathrm{g}^{-1}$ of support). The lipase-support system was maintained in contact for $16 \mathrm{~h}$ at $4^{\circ} \mathrm{C}$ under static conditions. The immobilized lipase derivatives were recovered by filtration under vacuum, with subsequent washing with hexane. The immobilized derivatives were dried under vacuum for different periods of time in order to attain moisture contents at the required level (5-20\%). After drying under vacuum, the biocatalyst moisture content was verified by gravimetric drying using a moisture determination balance (Marte ID 50, Marte Científica, São Paulo, Brazil). The immobilized derivative displayed an average hydrolytic activity of $4150 \mathrm{U} \mathrm{g}^{-1}$ using emulsified olive oil as the substrate (SOARES et al., 1999). Additional properties of the biocatalyst are given elsewhere (PAULA et al., 2010b).

\subsection{Evaluation of the reaction conditions for milkfat and soybean oil enzymatic interesterification}

The batch interesterification reactions were carried out in an inert nitrogen atmosphere in jacketed cylindrical glass reactors $(80 \mathrm{~mL})$ containing $40 \mathrm{~g}$ of reaction medium (65\% milkfat and $35 \%$ soybean oil) (PAULA et al., 2010a), assessing the influence of the following variables: biocatalyst loading (250-1500 units of activity per gram of reaction medium), biocatalyst moisture content (5-20\%) and temperature $\left(45-60^{\circ} \mathrm{C}\right)$. All the reactions were catalyzed by the lipase from $R$. oryzae immobilized on $\mathrm{SiO}_{2}-\mathrm{PVA}$, for a maximum period of $48 \mathrm{~h}$ under magnetic agitation (500 rpm), following the experimental sequence shown in Table 1. The reaction progress was monitored by determining the free fatty acid content, triacylglycerol composition (TAGs, carbon number) and consistency for both the non-interesterified blends and interesterified products. 
Assessing the reaction conditions to mediate the milkfat-soybean oil enzymatic interesterification

Paula, A. V. et al.

Table 1. Experimental sequence used to establish the reaction conditions for the enzymatic interesterification of milkfat with soybean oil.

\begin{tabular}{|c|c|c|c|}
\hline Reaction conditions & $\begin{array}{l}\text { Biocatalyst loading } \\
\text { (Units of activity per gram } \\
\text { of reaction medium) }\end{array}$ & $\begin{array}{l}\text { Biocatalyst moisture } \\
\text { content }(\%)\end{array}$ & $\begin{array}{c}\text { Temperature } \\
\left({ }^{\circ} \mathbf{C}\right)\end{array}$ \\
\hline \multicolumn{4}{|l|}{ Sequence of experiments } \\
\hline $\begin{array}{l}\text { 1. Biocatalyst loading } \\
\text { (units of activity per gram of reaction medium)* }\end{array}$ & $250 ; 500 ; 750 ; 1000 ; 1500$ & 10 & 45 \\
\hline 2. Biocatalyst moisture content $(\%)^{*}$ & Selected in 1 & $5 ; 10 ; 20$ & 45 \\
\hline 3. Temperature $\left({ }^{\circ} \mathrm{C}\right)^{*}$ & Selected in 1 & Selected in 2 & $45 ; 50 ; 60$ \\
\hline 4. Reaction time ${ }^{\star \star}$ & Selected in 1 & Selected in 2 & Selected in 3 \\
\hline
\end{tabular}

*48 $\mathrm{h}$ of reaction. ${ }^{*}$ Sampling was carried out after 2, 4, 6, 12, 24 and $48 \mathrm{~h}$.

\subsection{Analytical methods}

\subsubsection{Free fatty acid content}

The AOCS (HORWITZ, 2004) method Ca 5a-40 was used for the determination of total free fatty acids (FFA), which was expressed in terms of the percentage of free oleic acid.

\subsubsection{Triacylglycerol (TAG) composition}

The TAG composition, in carbon numbers, was analyzed by gas chromatography using a Varian CG 3800 model (Varian, Inc. Corporate Headquarters, Palo Alto, CA, USA) equipped with a flame ionization detector and a $3 \%$ OV1 Silpt-WBM 100/120 mesh Silco Var packed column (Restek, Frankel Commerce of Analytical Instruments Ltd, SP, Brazil). Nitrogen was used as the carrier gas, with a flow rate of $40 \mathrm{~mL} \mathrm{~min}^{-1}$. The detector and injector temperatures were $350{ }^{\circ} \mathrm{C}$ and $370{ }^{\circ} \mathrm{C}$, respectively. The column temperature was first set at $80^{\circ} \mathrm{C}$ for $1 \mathrm{~min}$, then programmed to increase at $50^{\circ} \mathrm{C} \mathrm{min}^{-1}$ to $210^{\circ} \mathrm{C}$, kept constant for $1 \mathrm{~min}$, then increased to $340^{\circ} \mathrm{C}$ at $6{ }^{\circ} \mathrm{C} \mathrm{min}{ }^{-1}$ and finally kept constant for a further $2 \mathrm{~min}$. The injection volume was $1 \mu \mathrm{L}$. Before injection, the samples were diluted in $2 \mathrm{~mL}$ of heptane and tetradecane was added as the internal standard. The chromatograms were processed using the Galaxie Chromatography Data System, version 1.9. The TAG calibration curve was prepared using the butterfat standard from the Community Bureau of Reference Materials (PRECHT; MOLKENTIN, 1997) (an example of the chromatogram is shown in the Annex A, Figure A1). The interesterification yield (IY) was defined according to Paula et al. (2010b).

\subsubsection{Consistency}

The consistency of the raw materials and interesterified products was determined using a texture analyzer (TA XT Plus, Texture Analyser, Stable Micro Systems, England). The samples were first heated in a microwave oven $\left(55-60{ }^{\circ} \mathrm{C}\right)$ to completely melt the crystals and then conditioned in a glass beaker $(100 \mathrm{~mL})$ for $48 \mathrm{~h}$ at $10^{\circ} \mathrm{C}$. The TA15 probe was used, corresponding to an acrylic cone with an angle of $45^{\circ}$, under the following conditions: number of cycles - 1; distance - $10 \mathrm{~mm}$; speed, $120 \mathrm{~mm} \mathrm{~min}^{-1}$; and time - 5s. The force during compression (gf) was determined in duplicate. The measurements were used to calculate the "yield value", which was defined according to Equation 1 (HAIGHTON, 1959) as follows:

$C=K \frac{W}{p^{1.6}}$

where: $\mathrm{C}$ is the "yield value" ( $\mathrm{gf} \mathrm{cm}^{-2}$ ), $\mathrm{K}$ is a constant depending on the cone angle (4700 for $\left.45^{\circ}\right), \mathrm{W}$ is the maximum compression force (gf) for $5 \mathrm{~s}$, and $\mathrm{p}$ is the penetration depth (in $0.1 \mathrm{~mm}$ ).

\section{Results and discussion}

Quantification of the modifications occurring in the TAG composition during the interesterification reactions of milkfat and vegetable oil blends is a complex task, mainly due to the variety of fatty acids that can be combined to form new TAGs. One of the approaches cited in the literature was reported by Rousseau and Marangoni (1998), in which the evolution of the TAG species was measured from the ratio of the relative proportions of the carbon species present in the blend and in the interesterified product.

This methodology was used in the present work, and taking into consideration the complex fatty acid composition varying from C4 to C24 (milkfat) and from C8 to C18 (soybean oil), the reaction blend can provide CN from 24 to 54, as illustrated in Figure A2 (Annex A).

Figure 1a-e shows the modifications caused in the relative proportions of the different carbon species in the interesterified products as compared to the non-interesterified blend using biocatalyst loadings of from 250-1500 units of activity per gram of blend. The corresponding interesterification yields (IY) and free fatty acid contents (\%) can be seen in Figure 2a-b.

The concentrations of carbon species $\mathrm{C}_{32}-\mathrm{C}_{42}$ and $\mathrm{C}_{54}$ decreased, whereas those of $\mathrm{C}_{46}-\mathrm{C}_{52}$ increased, regardless of the biocatalyst loading used in the reactions. In all the experiments, the main variation occurred in the TAG $\mathrm{C}_{50}$ content, while almost no change was observed in TAG $\mathrm{C}_{44}$. 
Assessing the reaction conditions to mediate the milkfat-soybean oil enzymatic interesterification

Paula, A. V. et al.
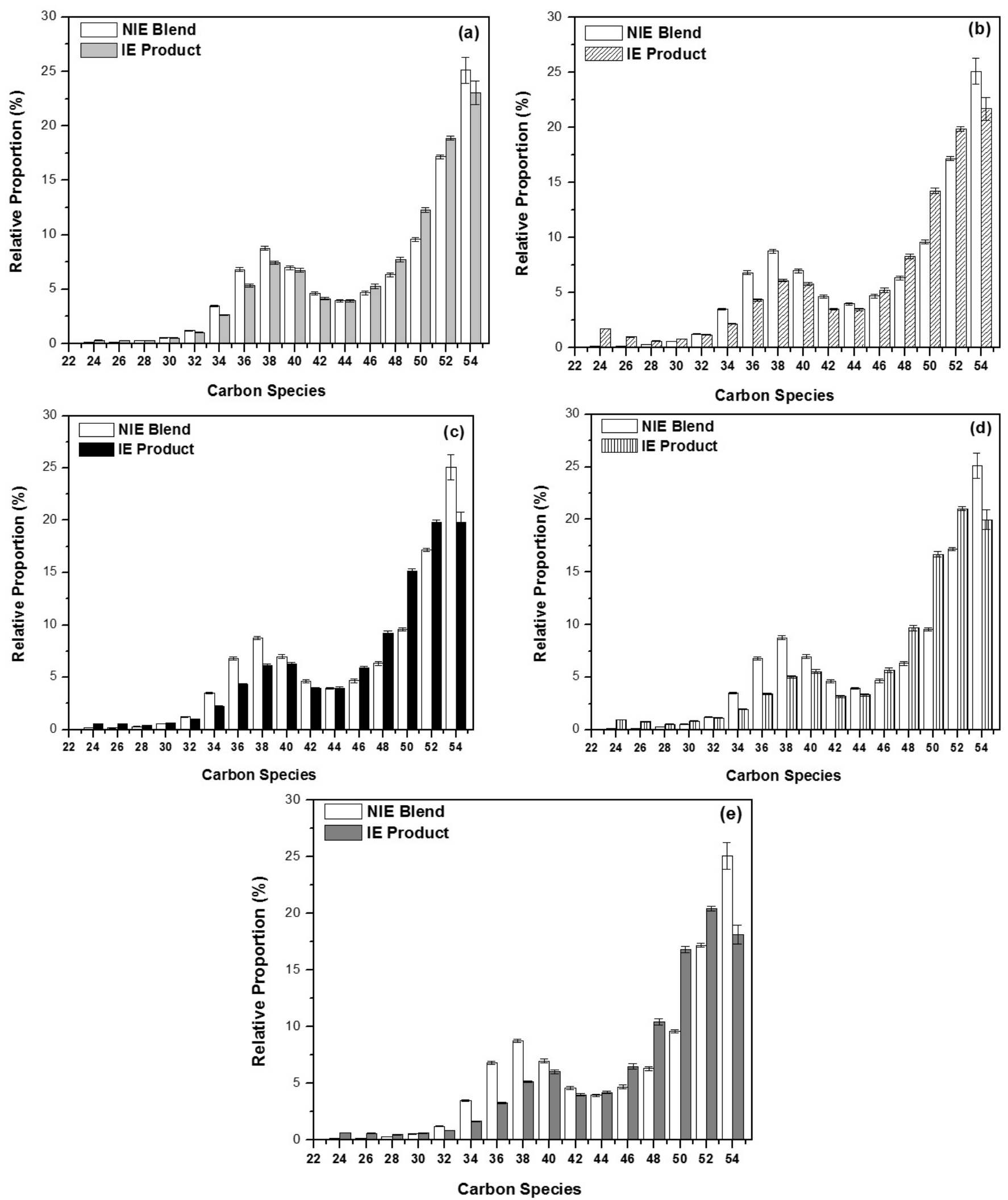

Figure 1. Relative proportion of carbon species in the NIE blend and IE products obtained in the interesterification reactions of milkfat with soybean oil catalyzed by $R$. oryzae lipase immobilized on $\mathrm{SiO}_{2}-\mathrm{PVA}$, having $10 \%$ of moisture. The reactions were carried out with different biocatalyst loadings: (a) 250; (b) 500; (c) 750; (d) 1000 and (e) 1500 units of activity per gram of blend, for $48 \mathrm{~h}$ at $45{ }^{\circ} \mathrm{C}$. 
Using the TAG concentrations, the values calculated for the interesterification yield (IY) varied from $10.8 \pm 1.4$ to $31.4 \pm 4.0 \%$ (Figure $2 a$ ). The maximum interesterified yield obtained was $31.4 \pm 4.01 \%$, although this value must be carefully evaluated. It is an indication of the extension of the interesterification, and since these kinds of reaction tend to reach equilibrium, $100 \%$ is not a target or even a reachable value. For the purpose of this work, the target is to promote enough compositional changes to enhance some properties such as the spreadability of the material.

The lowest IY value $(10.8 \pm 1.4 \%)$ was achieved in the reactions carried out with $250 \mathrm{U}$ of biocatalyst per gram of medium. As the biocatalyst loading increased two
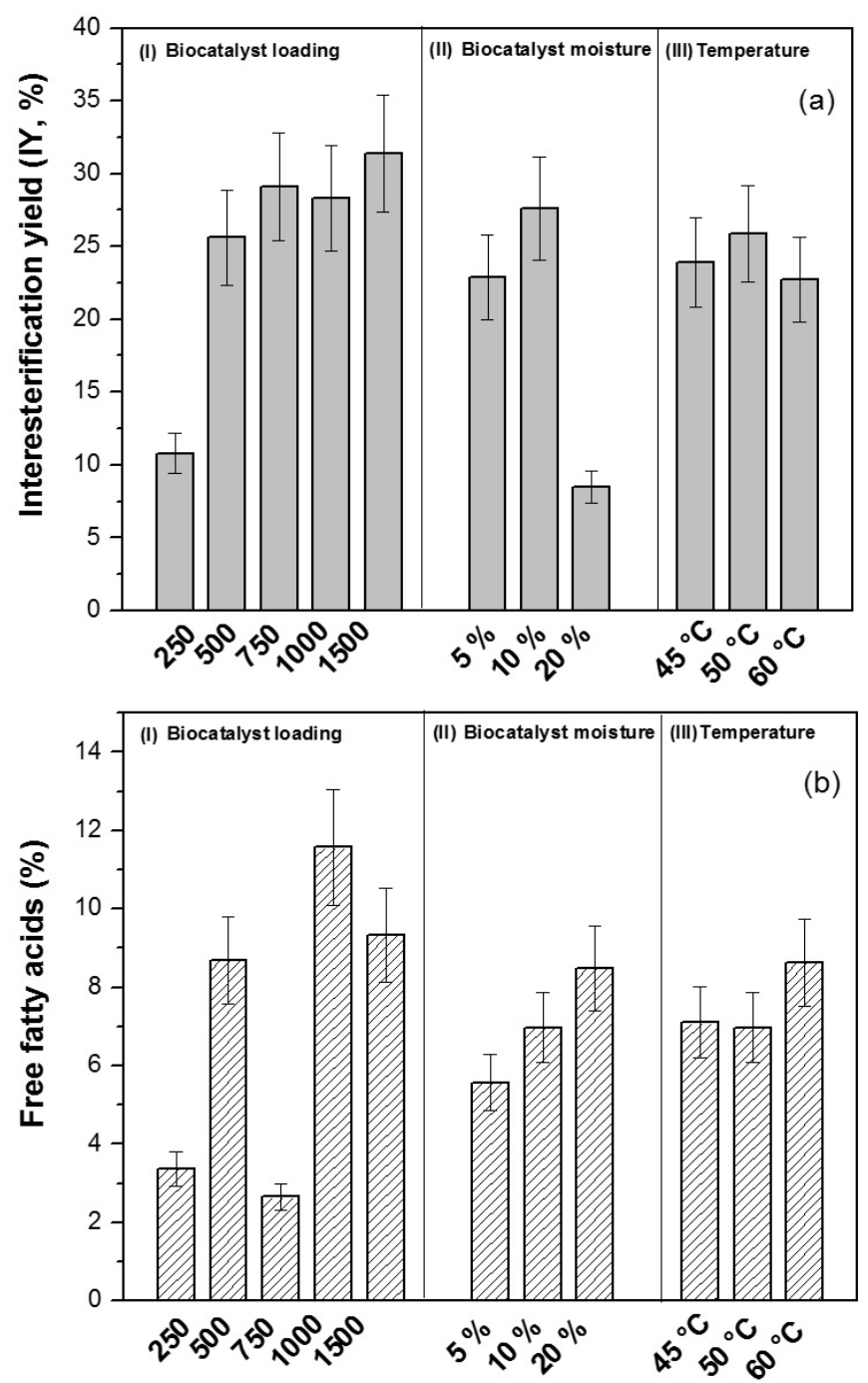

Figure 2. Interesterification yield (a) and free fatty acid content (b) values (average \pm standard deviation) for the IE products obtained in the interesterification reactions of milkfat with soybean oil catalyzed by $R$. oryzae lipase immobilized on $\mathrm{SiO}_{2}-\mathrm{PVA}$, as a function of: the biocatalyst loading (units of activity per gram of blend) (I); the biocatalyst moisture content (II); and the reaction temperature (III). fold, so the IY value increased proportionally, as expected. However, when the biocatalyst loading was above $500 \mathrm{U} \mathrm{g}^{-1}$, no substancial increase in IY was observed. Although the highest IY value $(31.4 \pm 4.0 \%)$ was obtained using the $1500 \mathrm{U} \mathrm{g}^{-1}$ blend, such a result does not represent a substantial increase in relation to that obtained using $500 \mathrm{U} \mathrm{g}^{-1}$ blend $(25.6 \pm 3.3 \%)$. The free fatty acid content varied from $2.7 \pm 0.3$ to $11.6 \pm 1.5 \%$, depending on the biocatalyst loading used (Figure 2b).

The consistency of the products resulting from each reaction was also determined to assess the changes caused in the texture properties of the original blend by the interesterification (Figure 3, region I). The results showed that the consistency of all the interesterified products decreased in relation to the non-interesterified blend, which had a consistency value of $1159.8 \pm 169.8 \mathrm{gf} \mathrm{cm}^{-2}$. All runs yielded interesterified products with consistency values within the desirable range (200 to $800 \mathrm{gf} \mathrm{cm}^{-2}$ ), according to the criteria established by Haighton (1959) to attend the plasticity property requirements, except for those carried out with a biocatalyst loading above $1000 \mathrm{U} \mathrm{g}^{-1}$, which resulted in consistency values lower than $200 \mathrm{gf} \mathrm{cm}^{-2}$ (Figure 3, region I).

By analyzing the results obtained in this set of experiments, the reaction carried out with the $500 \mathrm{U} \mathrm{g}^{-1}$ blend provided the best set of results in terms of interesterified yield $(25.6 \pm 3.8 \%)$, free fatty acid content $(8.7 \pm 1.1 \%)$ and consistency $\left(446.0 \pm 25.3 \mathrm{gf} \mathrm{cm}^{-2}\right)$, and was therefore selected to be used in the following experiments.

At a molecular level, interesterification reactions involve ester hydrolysis followed by re-esterification

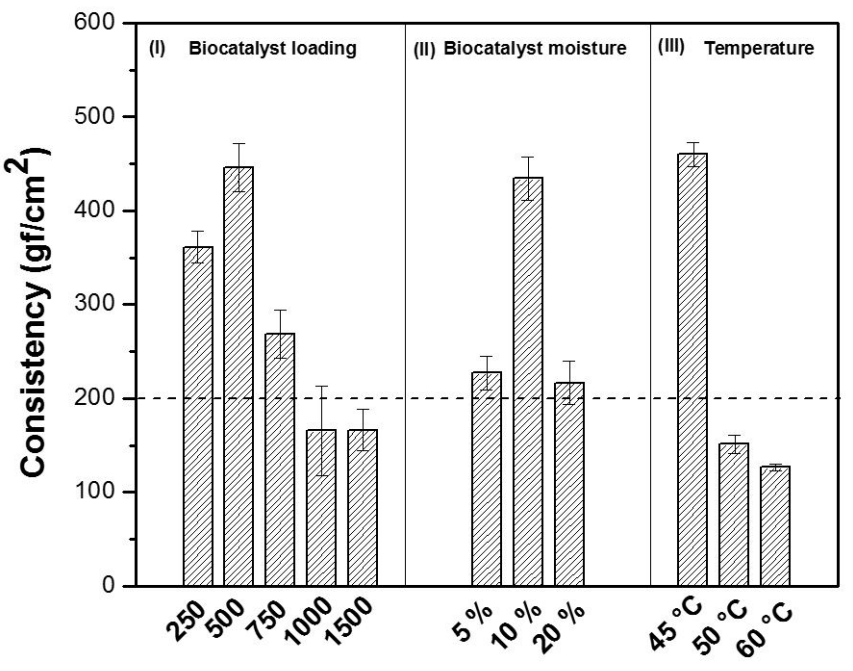

Figure 3. Consistency values (average \pm standard deviation, $10^{\circ} \mathrm{C}$ ) of the interesterified products as a function of: the biocatalyst loading (units of activity per gram of blend) (I); the biocatalyst moisture content (II); the reaction temperature (III). The non-interesterified blend had a consistency value of $1159.8 \pm 169.8 \mathrm{gf} \mathrm{cm}^{-2}$. 
Assessing the reaction conditions to mediate the milkfat-soybean oil enzymatic interesterification

Paula, A. V. et al.

(MARANGONI, 2002). Therefore, depending on the water content in the reaction medium, free fatty acid accumulation is favoured (OSÓRIO et al., 2009). Thus, evaluating the influence of the water content provided by the biocatalyst should be of paramount importance.

The modifications observed during the interesterification reactions using the biocatalyst with different water contents are displayed in Figure $4 \mathrm{a}-\mathrm{c}$, which compares the TAG composition of the non-interesterified blends and interesterified products after $48 \mathrm{~h}$ reaction.

Regardless of the biocatalyst moisture content, the levels of carbon species $\mathrm{C}_{24}-\mathrm{C}_{26}$ and $\mathrm{C}_{46}-\mathrm{C}_{52}$ increased, while those of $\mathrm{C}_{30}-\mathrm{C}_{32}$ and $\mathrm{C}_{42}$ and $\mathrm{C}_{54}$ decreased. Figure 2 shows the influence of the biocatalyst moisture content on the performance of the interesterification reactions in relation to the interesterification yield (IY) and free fatty acid content (\%), after $48 \mathrm{~h}$. Using biocatalysts containing $5 \%$ and $20 \%$ of moisture, the lowest (5.6 $\pm 0.7 \%$ ) and highest $(8.6 \pm 1.1 \%)$ free fatty acid levels were obtained, respectively.

With respect to the interesterification yield (IY), the lowest value $(22.9 \pm 2.9 \%)$ was achieved with the biocatalyst containing $5 \%$ of moisture (Figure 2, Region II). This result can be better understood by evaluating the importance of the moisture level in the reactions catalysed by lipases. As previously discussed, water plays a fundamental role in the interesterification reactions, since it is responsible for the equilibrium between hydrolysis and esterification. In addition, water is required to maintain the catalytic function of these enzymes since it contributes, either directly or indirectly, to all the interactions that maintain the conformation of the active site, and consequently, the
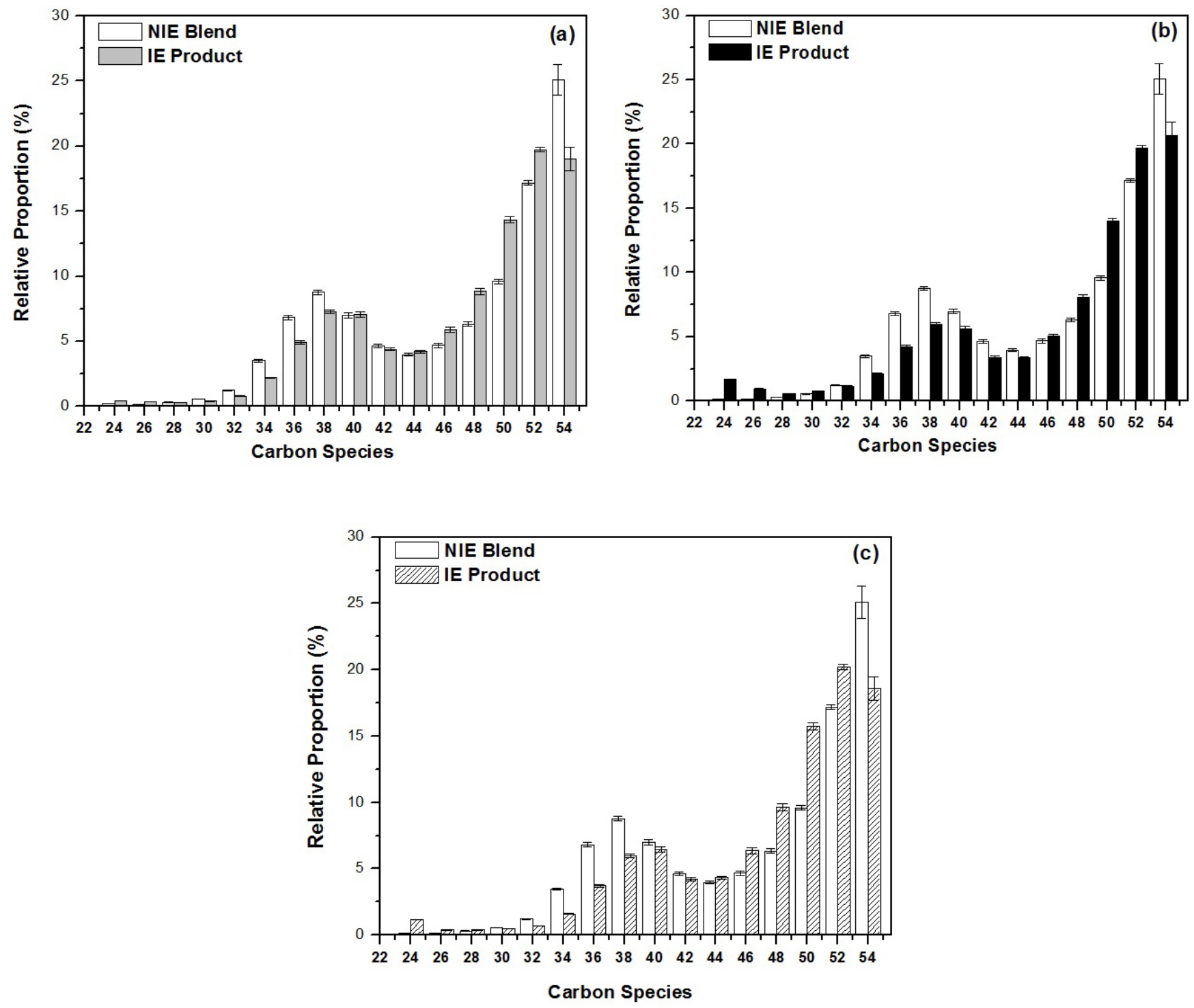

Figure 4. Relative proportions of carbon species in the NIE blend and IE products obtained in the interesterification reactions of milkfat with soybean oil catalysed by $R$. oryzae lipase immobilized on $\mathrm{SiO}_{2}$-PVA. The reactions were carried out at a fixed biocatalyst loading (500 units) with different moisture contents: (a) 5\%; (b) $10 \%$; and (c) $20 \%$, and a fixed temperature $=45^{\circ} \mathrm{C}$. 
Assessing the reaction conditions to mediate the milkfat-soybean oil enzymatic interesterification

Paula, A. V. et al.

catalytic function of these biocatalysts (BODALO et al., 2009). It is probable that the amount of water present in the reaction medium was not sufficient to maintain the catalytic activity of the lipase when the biocatalyst moisture content was only $5 \%$. On the other hand, the excessive amount of water provided by the biocatalyst containing $20 \%$ of moisture favoured the hydrolysis reaction, as confirmed by the high level of free fatty acid content.

In the reaction catalysed by the biocatalyst containing $10 \%$ of moisture, a high IY value $(27.6 \pm 3.5 \%)$ was obtained (Figure 2). In this case, the water loading supplied to the reaction medium seems to be at an adequate level to maintain the catalytic activity of the biocatalyst, while at the same time controlling the occurrence of the hydrolysis reaction (about $7 \%$ of free fatty acid content). It should be noted that $10 \%$ of moisture content is the specification of a particular commercial preparation of immobilized lipase (Lipozyme) which is regarded as one of the most effective lipases to mediate interesterification reactions.
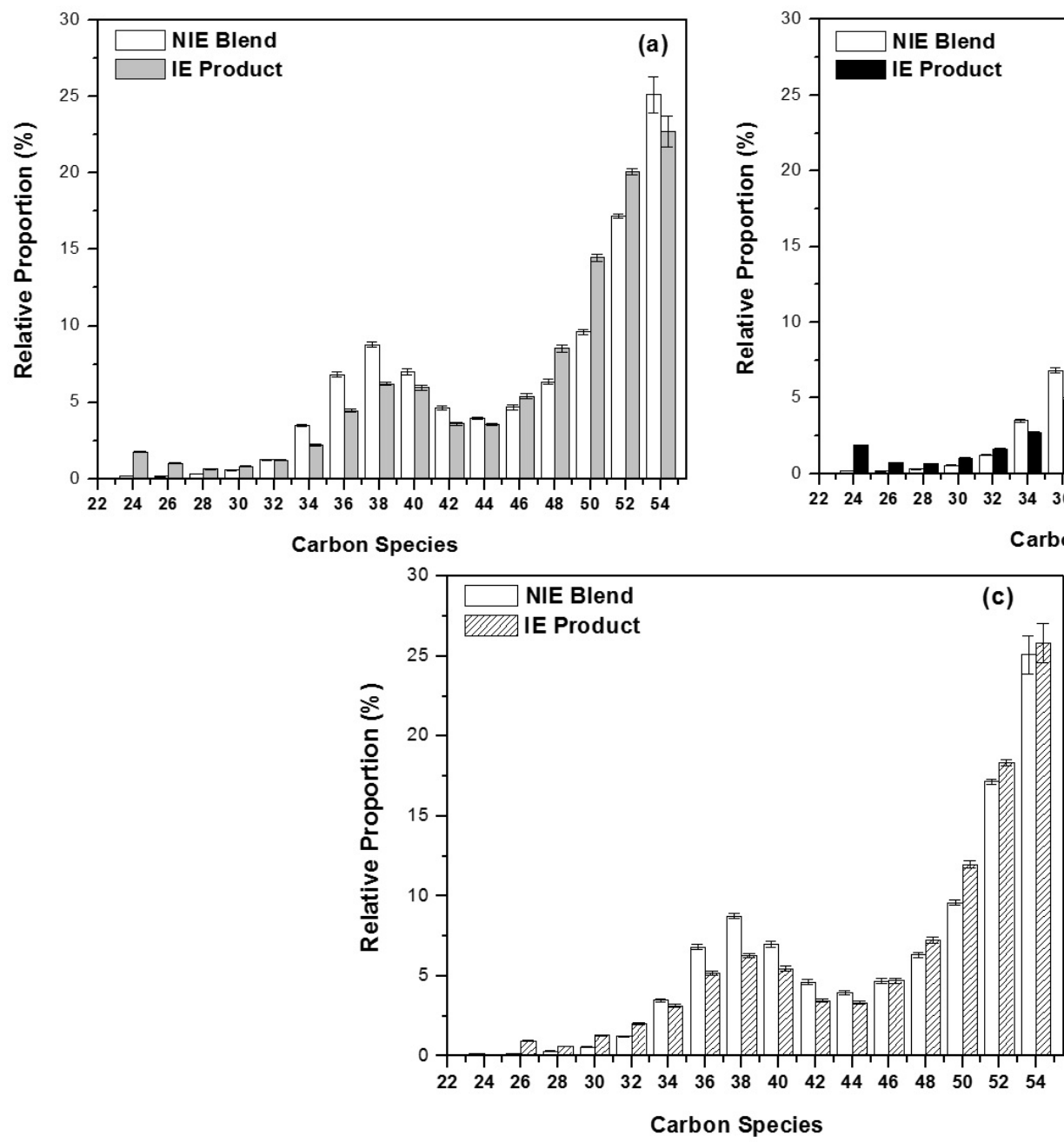

Figure 5. Relative proportion of carbon species in the NIE blend and IE products obtained in the interesterification reactions of milkfat with soybean oil catalysed by $R$. oryzae lipase immobilized on $\mathrm{SiO}_{2}-\mathrm{PVA}$. The reactions were carried at a fixed biocatalyst loading (500 units) with $10 \%$ of moisture, but at different temperatures: (a) $45^{\circ} \mathrm{C}$; (b) $50{ }^{\circ} \mathrm{C}$ and (c) $60^{\circ} \mathrm{C}$.
In order to evaluate the changes promoted in the texture properties of the interesterified products,

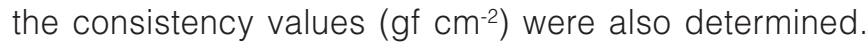
As shown in Figure 3 (region II), the interesterified products obtained from the reaction carried out with biocatalysts having $5 \%$ and $20 \%$ of moisture, resulted in consistency values near the minimum limit (200 $\left.\mathrm{gf} \mathrm{cm}^{-2}\right)$.

Therefore, the biocatalyst with $10 \%$ of moisture was selected as it resulted in adequate consistency values $\left(434.4 \pm 23.1 \mathrm{gf} \mathrm{cm}^{-2}\right)$ with comparatively high interesterification yields $(27.6 \pm 3.5 \%)$ and a free fatty acid level of $6.9 \pm 0.9 \%$.

Another variable studied in the interesterification reactions was temperature. The reactions were carried out at three different temperatures: 45,50 and $60{ }^{\circ} \mathrm{C}$. Higher temperatures were not assessed in order to avoid oxidation of the blend components.

The relative proportions of carbon species obtained in the reactions carried out using the biocatalysts at different temperatures are shown in Figure 5. In general,

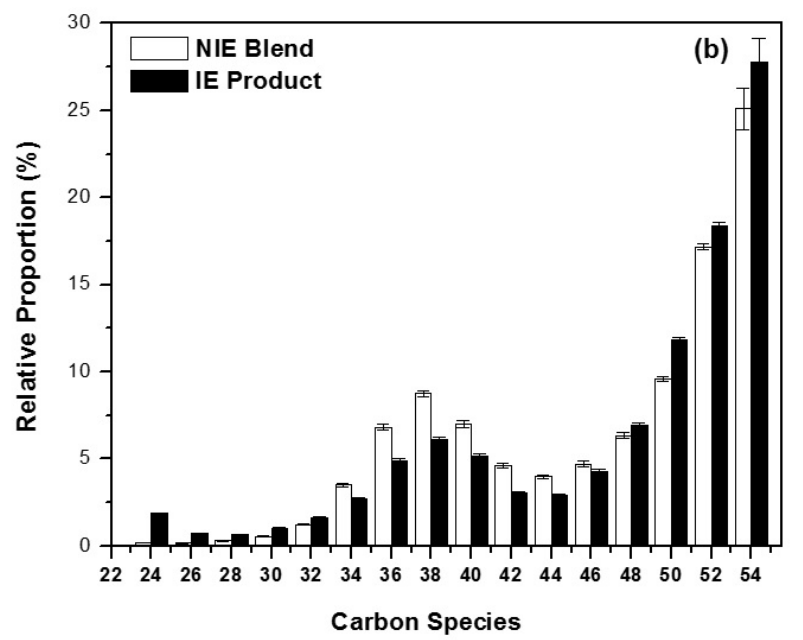

(c) 
regardless of the reaction temperature tested, the levels of carbon species $\mathrm{C}_{26}-\mathrm{C}_{32}$ and $\mathrm{C}_{48}-\mathrm{C}_{54}$ increased, while those of $\mathrm{C}_{34}-\mathrm{C}_{44}$ decreased. In addition, in the reaction carried out at $60^{\circ} \mathrm{C}$ (Figure $5 \mathrm{c}$ ), the absence of carbon species $\mathrm{C}_{24}$ could be observed in the interesterified product, while it underwent a considerable increase in the other reactions.

The interesterification yield (IY) values were calculated from the TAG concentration levels and displayed in Figure 2 (region III), along with their respective levels of free fatty acid content (\%).

In terms of the free fatty acid contents, except for the reaction catalysed at $60^{\circ} \mathrm{C}$ which provided the highest value $(8.6 \pm 1.1 \%)$, the liberation of free fatty acid was maintained to the order of $7.0 \%$ for the other temperatures tested $\left(45^{\circ}\right.$ and $\left.50{ }^{\circ} \mathrm{C}\right)$. According to the literature, the presence of free fatty acids can indicate the occurrence of partial hydrolysis, resulting in mono- and diacylglycerols that can act as emulsifiers (KAEWTHONG et al., 2005).

In terms of the interesterification yield (IY), the highest value was obtained in the reaction carried out at $50{ }^{\circ} \mathrm{C}(25.9 \pm 3.3 \%)$. However, it is important to note that the temperature of $45{ }^{\circ} \mathrm{C}$ provided a similar result $(23.9 \pm 3.1 \%)$, while higher temperatures $\left(60^{\circ} \mathrm{C}\right)$ resulted in the lowest IY value $(22.7 \pm 2.9 \%)$.

These results can be explained by evaluating the importance of temperature in the enzymatic reactions. Most chemical reactions take place at a higher rate as the temperature increases, since an increase in temperature provides greater kinetic energy for the reactant molecules, causing a greater number of productive collisions per unit time. Reactions catalysed by enzymes exhibit a similar behaviour to chemically catalysed reactions. However, if the biocatalyst molecule absorbs excessive energy, the tertiary structure breaks down and the enzyme is denatured, thus losing its catalytic activity (SILVA et al., 2009). Thus as the temperature increases, the reaction rate is also expected to increase, although higher temperatures can favour denaturation of the biocatalyst and activity loss.

Besides the IY and percentage of free fatty acid content, the consistency values $\left(\mathrm{gf}^{-2}\right)$ were also determined. Figure $5 \mathrm{c}$ shows the values obtained for each of the interesterified products depending on the reaction temperature. The consistency of all the interesterified products declined in comparison with the original blend $\left(1159.8 \pm 169.8 \mathrm{gf} \mathrm{cm}^{-2}\right)$.

By analysing the results in terms of interesterification yield and free fatty acid content, it was found that, although the temperature of $50^{\circ} \mathrm{C}$ provided the most suitable values for the process, i.e., higher interesterification yield (25.9\%) and liberation of free fatty acids (6.9\%), it caused a sharp reduction in product consistency. Only the interesterified product obtained from the reaction catalysed at $45{ }^{\circ} \mathrm{C}$ provided products with consistency values within the range (200 to $800 \mathrm{gf} \mathrm{cm}^{-2}$ ) established by Haighton (1959).
Thus it was found that at a temperature of $45^{\circ} \mathrm{C}$, an appropriate consistency value $\left(459.9 \pm 13.0 \mathrm{gf} \mathrm{cm}^{-2}\right)$, a satisfactory IY value $(23.9 \pm 3.1 \%)$ and free fatty acid level $(7.1 \pm 0.9 \%)$ were obtained, and hence this temperature was found to be suitable for carrying out the interesterification reaction successfully. Furthermore, higher temperatures increased the energy costs and contributed to oxidization of the product, changing its sensory characteristics.

Further experiments were carried out to assess the influence of the reaction time on the parameters. Figure 6 shows the interesterification yield and free fatty acids (\%) obtained for the interesterification reactions at different reaction times.

Figure 6 shows that the free fatty acid content increased in the first $6 \mathrm{~h}$, reaching approximately $7 \%$, and then increased more slowly to a maximum of $7.6 \pm 0.9 \%$ at the end of the reaction time ( $48 \mathrm{~h}$ ). Regarding the interesterification yield, this increased in the first $6 \mathrm{~h}$ to a value of $8.9 \pm 0.1 \%$, and then increased more slowly to a maximum of $24.1 \pm 1.4 \%$ after $48 \mathrm{~h}$. These results agree with those found in the literature. Aguedo et al. (2008) studied the enzymatic interesterification of milk fat with linseed oil, catalysed by the commercial lipase Lipozyme for $24 \mathrm{~h}$, and observed that the greatest changes in the composition occurred in the first $6 \mathrm{~h}$ of reaction time.

The results for interesterification yield can be related to the consistency of the interesterified products (average value \pm standard deviation), as shown in Figure 7 . It can be seen that after $6 \mathrm{~h}$ of reaction time there were no further great changes in consistency, but up to $2 \mathrm{~h}$ of reaction time, the consistency values were near to the upper limit $\left(800 \mathrm{gf}^{-2}\right)$, indicating that this time was insufficient to promote the desired changes in the physical properties of the interesterified products. Reaction times

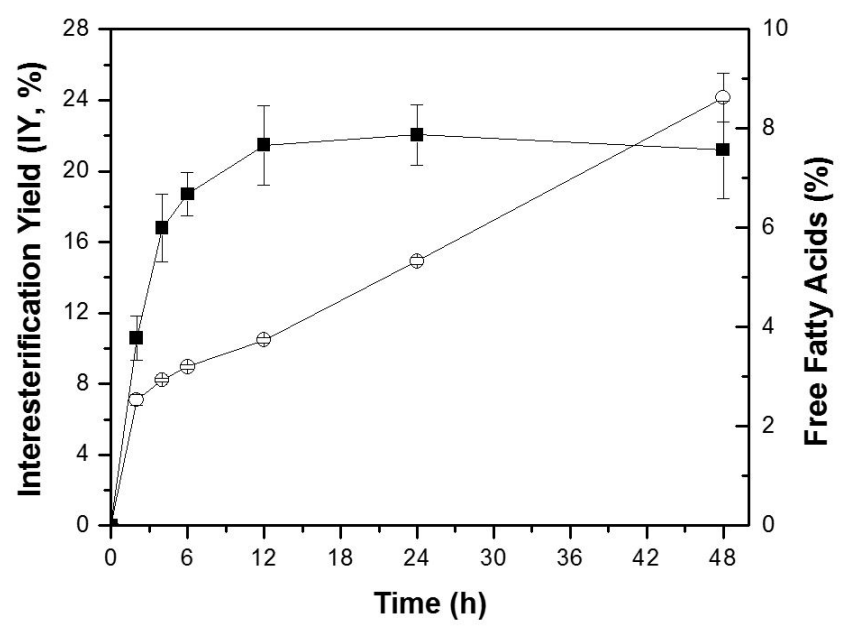

Figure 6. Interesterification yield $(\%, 0)$ and free fatty acid content $(\%, \boldsymbol{m})$ values (average \pm standard deviation) for the IE products obtained in the interesterification reactions of milkfat with soybean oil catalysed by $R$. oryzae lipase immobilized on $\mathrm{SiO}_{2}$-PVA at different times. 


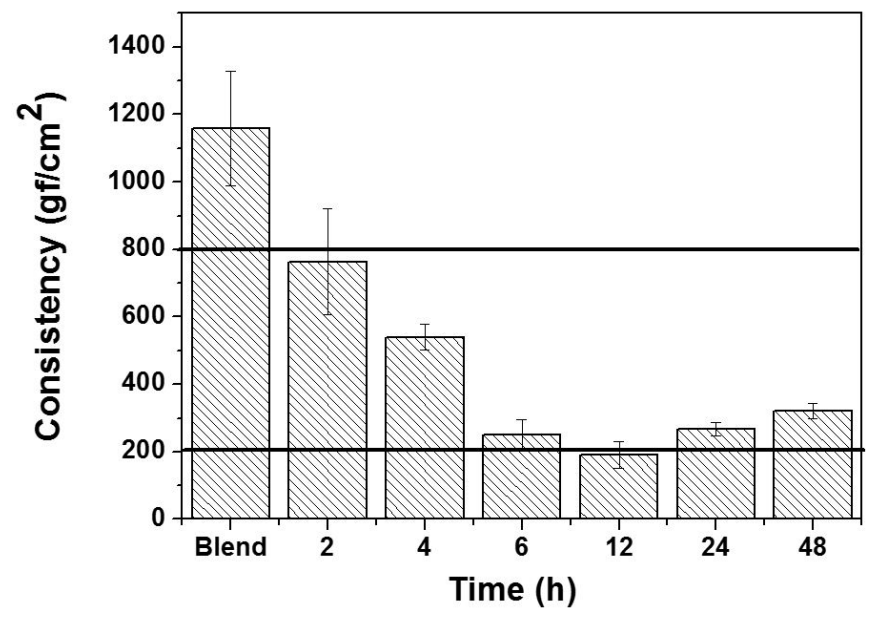

Figure 7. Consistency values (average \pm standard deviation, $10^{\circ} \mathrm{C}$ ) of the interesterified products as a function of the reaction time. The non-interesterified blend had a consistency value of $1159.8 \pm 169.8 \mathrm{gf} \mathrm{cm}^{-2}$.

of 4 and 6 h resulted in products with consistency values within the range considered ideal (200-800 $\mathrm{gf} \mathrm{cm}^{-2}$ ), with satisfactory spreadability properties (HAIGHTON, 1959). However, after 6 h of reaction time, the product consistency was close to the lower limit of the recommended range $\left(251.47 \pm 44.45 \mathrm{gf} \mathrm{cm}^{-2}\right)$, indicating $4 \mathrm{~h}$ as the best time to end the reaction.

\section{Conclusions}

In interesterification reactions catalysed by lipases, several factors must be taken into account to ensure that the biocatalyst activity and reaction yield are optimal, and the main parameters include: temperature, water content and biocatalyst loading to be used in the reaction medium. These factors were studied in the enzymatic interesterification reaction of milkfat with soybean oil, catalysed by the lipase from Rhizopus oryzae immobilized on $\mathrm{SiO}_{2}-\mathrm{PVA}$. The reaction conditions were set based on the parameters that provided a high interesterification yield and final product consistency within the ideal range (200 to $800 \mathrm{gf} \mathrm{cm}^{-2}$ ). To attend this set of parameters, the following conditions were chosen: $500 \mathrm{U}$ of activity per gram of blend, $10 \%$ of moisture content and temperature of $45^{\circ} \mathrm{C}$. Under these conditions, the influence of the reaction time was investigated and $4 \mathrm{~h}$ was found to be adequate to reach a desirable consistency value $\left(539 \pm 38 \mathrm{gf} \mathrm{cm}^{-2}\right)$, which is considered to be suitable for a satisfactory fat with plasticity and spreadability.

\section{Acknowledgements}

The authors gratefully acknowledge the financial support received from the Fundação de Amparo à Pesquisa do Estado de São Paulo (FAPESP).

\section{References}

AGUEDO, M.; HANON, E.; DANTHINE, S.; PAQUOT, M.; LOGNAY, G.; THOMAS, A.; VANDENBOL, M.; THONART, P.; WATHELET, J. P.; BLECKER, C. Enrichment of anhydrous milk fat in polyunsaturated fatty acid residues from linseed and rapeseed oils through enzymatic interesterification. Journal of Agricultural and Food Chemistry, Washington, v. 56, n. 5, p. 1757-1765, 2008. http:// dx.doi.org/10.1021/jf0722203. PMid:18271538.

BODALO, A.; BASTIDA, J.; MAXIMO, M. F.; MONTIEL, M. C.; MURCIA, M. D.; ORTEGA, S. Influence of the operating conditions on lipase - catalysed synthesis of ricinoleic acid estolides in solvent-free systems. Biochemical Engineering Journal, Lausanne, v. 44, n. 2-3, p. 214-219, 2009. http://dx. doi. org/10.1016/j.bej.2008.12.007.

FERRARIO, V.; VENY, H.; DE ANGELIS, E.; NAVARINI, L.; EBERT, C.; GARDOSSI, L. Lipases immobilization for effective synthesis of biodiesel starting from coffee waste oils. Biomarkers, New York, v. 3, n. 3, p. 514-534, 2013. PMid:24970178.

FRIEDRICH, J. L. R.; PEÑA, F. P.; GARCIA-GALAN, C.; FERNANDEZLAFUENTE, R.; AYUB, M. A. Z.; RODRIGUES, R. C. Effect of immobilization protocol on optimal conditions of ethyl butyrate synthesis catalyzed by lipase B from Candida antarctica. Journal of Chemical Technology and Biotechnology, Chichester, v. 88, n. 6, p. 1089-1095, 2012. http://dx.doi.org/10.1002/jctb.3945.

HAIGHTON, A. J. The measurement of the hardness of margarine and fats with cone penetrometers. Journal of the American Chemical Society, Chicago, v. 36, n. 8, p. 345, 1959.

HORWITZ, W. (Ed.). Official methods and recommended practices of the AOCS. Washington: AOCS Press, 2004.

KAEWTHONG, W.; SIRISANSANEEYAKUL, S.; PRASERTSAN, P.; H-KITTIKUN, A. Continuous production of monoacylglycerols by glycerolysis of palm olein with immobilized lipase. Process Biochemistry, Barking, v. 40, n. 5, p. 1525-1530, 2005. http:// dx.doi.org/10.1016/j. procbio.2003.12.002.

MARANGONI, A. J. Lipases: structure, function, and properties. In: KUO, T. M.; GARDNER, H. W. Lipid biotechnology. New York: Marcel Dekker, 2002. 716 p.

MARTINS, A. B.; FRIEDRICH, J. L. R.; CAVALHEIRO, J. C.; GARCIA-GALAN, C.; BARBOSA, O.; AYUB, M. A. Z.; FERNANDEZLAFUENTE, R.; RODRIGUES, R. C. Improved production of butyl butyrate with lipase from Thermomyces lanuginosus immobilized on styrene-divinylbenzene beads. Bioresource Technology, Barking, v. 134, p. 417-422, 2013. http://dx.doi.org/10.1016/j. biortech.2013.02.052. PMid:23499180.

MUKHERJEE, A. K. Hydrophobic-hydrophilic interaction in lipase catalytic triad and possibility of a cofactor mediated catalysis. International Journal of Food Sciences and Nutrition, Basingstoke, v. 4, n. 3, p. 84, 2014.

NUNES, G. F. M.; PAULA, A. V.; CASTRO, H. F.; SANTOS, J. C. Modificação bioquímica da gordura do leite. Química Nova, São Paulo, v. 33, n. 2, p. 431, 2010. 
Assessing the reaction conditions to mediate the milkfat-soybean oil enzymatic interesterification

Paula, A. V. et al.

OSÓRIO, N. M.; DUBREUCQ, E.; DA FONSECA, M. M. R.; FERREIRA-DIAS, S. Operational stability of immobilised lipase/ acyltransferase during interesterification of fat blends. European Journal Lipid Science Technology, Berlin, v. 111, n. 4, p. 358-367, 2009. http://dx.doi.org/10.1002/ejlt.200800194.

PAULA, A. V.; NUNES, G. F. M.; FREITAS, L.; DE CASTRO, H. F.; SANTOS, J. C. Interesterification of milkfat and soybean oil blends catalyzed by immobilized Rhizopus oryzae lipase. Journal of Molecular Catalysis B-Enzymatic, Oxford, v. 65, n. 1-4, p. 117-121, 2010a. http://dx.doi.org/10.1016/j.molcatb.2009.12.008.

PAULA, A. V.; NUNES, G. F. M.; SILVA, J. L.; CASTRO, H. F.; SANTOS, J. C. Screening of food grade lipases to be used in esterification and interesterification reactions of industrial interest. Applied Biochemistry and Biotechnology, Riverside, v. 160, n. 4, p. 1146-1156, 2010b. http://dx.doi.org/10.1007/s12010009-8578-z. PMid:19263247.

PRECHT, D.; MOLKENTIN, J. The certification of the triglyceride contents of an anhydrous butter fat reference material with additional value for free cholesterol CRM 519. Luxembourg: Comission of the European Communities, 1997.
ROUSSEAU, D.; MARANGONI, A. G. Tailoring the textural attributes of butter fat/canola oil blends via Rhizopus arrhizus lipase-catalyzed interesterification. 1. Compositional modifications. Journal of Agricultural and Food Chemistry, Washington, v. 46, n. 6, p. 2368-2374, 1998. http://dx.doi.org/10.1021/jf970723a.

SILVA, V. C.; CONTESINI, F. J.; CARVALHO, P. O. Enantioselective behavior of lipases from Aspergillus niger immobilized in different supports. Journal of Industrial Microbiology \& Biotechnology, Texas, v. 36, n. 7, p. 949-954, 2009. http://dx.doi.org/10.1007/ s10295-009-0573-4. PMid:19390883.

SOARES, C. M. F.; DE CASTRO, H. F.; MORAES, F. F.; ZANIN, G. M. Characterization and utilization of Candida rugosa lipase immobilized on controlled pore silica. Applied Biochemistry and Biotechnology, Riverside, v. 77-79, n. 1-3, p. 745-757, 1999. http://dx.doi.org/10.1385/ABAB:79:1-3:745. PMid:15304694.

SOUMANOU, M. M.; PÉRIGNON, M.; VILLENEUVE, P. Lipasecatalyzed interesterification reactions for human milk fat substitutes production: a review. European Journal Lipid Science Technology, Berlin, v. 115, n. 3, p. 270-285, 2013. http://dx. doi. org/10.1002/ejlt.201200084. 
Assessing the reaction conditions to mediate the milkfat-soybean oil enzymatic interesterification

Paula, A. V. et al.

Annex A. Electronic Supplementary Material.

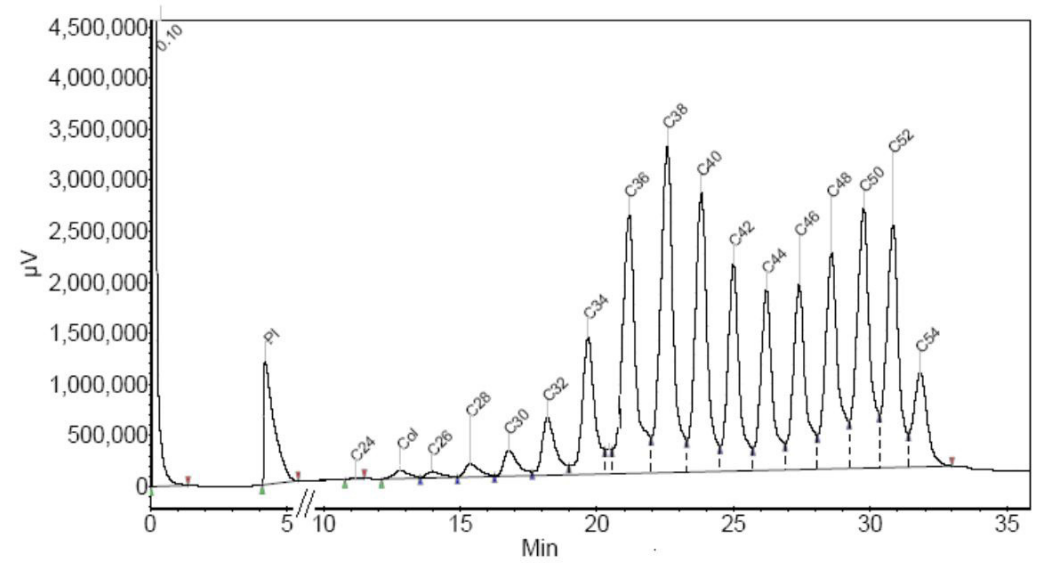

Figure A1. Typical chromatogram corresponding to the TAG profile of the butterfat standard from the Community Bureau of Reference Materials.

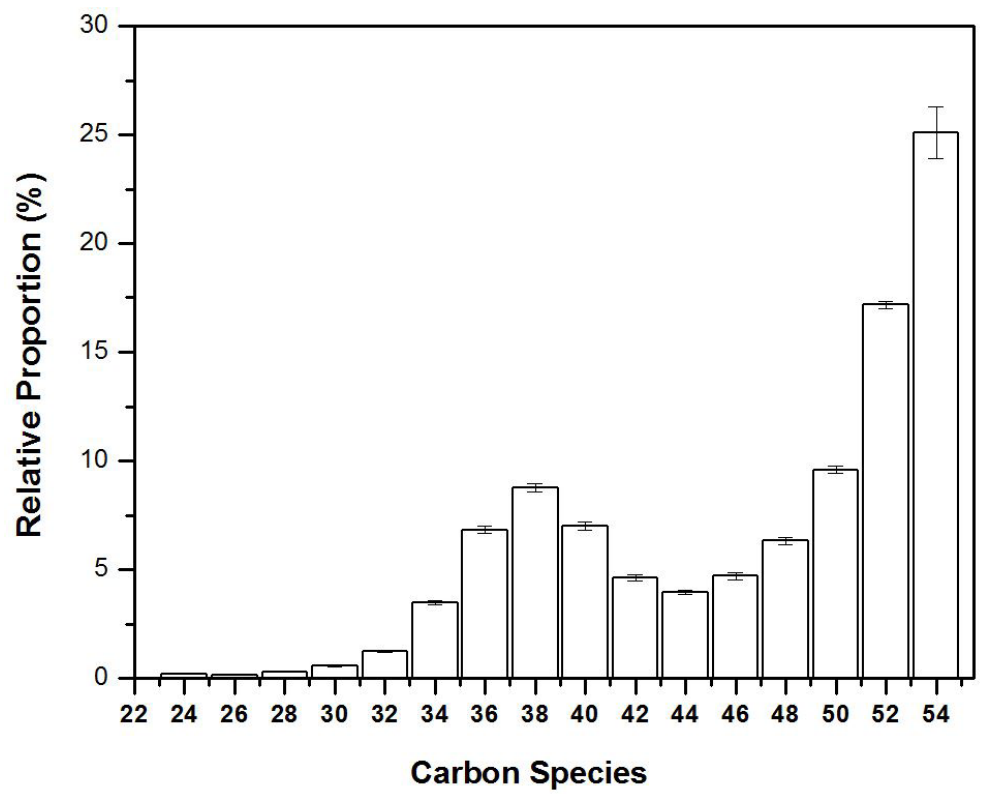

Figure A2. Relative proportion of carbon species in the NIE blend obtained in the interesterification reactions of milkfat with soybean oil catalysed by $R$. oryzae lipase immobilized on $\mathrm{SiO}_{2}-\mathrm{PVA}$. 